\title{
Development of cross-border education in regional University
}

\author{
Alexander Legkonogikh ${ }^{1 *}$, Galina Mezinova ${ }^{1}$, Svetlana Popova ${ }^{1}$, and Christina Karimova ${ }^{2}$ \\ ${ }^{1}$ Don State Technical University, Faculty "Social work", 344000, Rostov on Don, Russian \\ Federation \\ ${ }^{2}$ Academy of psychology and pedagogy, Department of Correctional pedagogy, 344065, \\ Rostov on Don, Russian Federation
}

\begin{abstract}
The purpose of the article is to substantiate the relevance of the development of cross-border education in regional university as an integral part of the innovative development of these universities and compliance with the trends of global globalization, including in higher education. The author's position is based on the results of monitoring of the teaching staff of the Don State Technical University (Rostov on Don), which confirmed that the University teachers positively assess the situation in this University, its professional, technical and communication resources for the development of cross-border education, but are not ready to fully integrate into this process due to the lack of qualification and motivated focus of the University on the effective development of international education. The article discusses different points of view on the trends in cross-border education in the Don State Technical University, reveals the reasons for the low penetration of cross-border education in regional universities.
\end{abstract}

\section{Introduction}

The relevance of the development of cross-border education is due to the intensification of the efforts of the global subjects of the educational market to the transition to international (cross-border) education against the background of globalization processes that are taking place today in all sectors and fields of activity. At the same time, it is still quite difficult for higher education institutions in the regions with a large base of human and professional resources to accept the conditions of the market environment and develop cross-border education at the level and quality that meet international standards.

The issue of cross-border (international) education is given attention in the publications of modern scientists and practitioners. In this article, the focus was on the work of Sedunovoy S.Y., Panibratzeva V.A., Lukicheva G.A., Shabalina Y.E, Vakhrusheva E.M., Shineaway A. I., Legkonogikh A.N., Krechetnikova K.G., and etc., in which the specificity of cross-border education, especially the implementation of international training programs

* Corresponding author: lan-666-121285@mail.ru 
at regional universities. The Report «Implementation of the recommendations of the UNESCO - OECD Guidelines on quality assurance in cross-border higher education», prepared by the Director of education of the Organization for economic cooperation and development (OECD) Stefan Vinsen-Lankran and Sebastian Fotenhauer (2012), which served as the basis for the subsequent conclusions and recommendations in the development of international education by the Don State Technical University, was considered.

The phenomenon of cross-border education is not yet sufficiently disclosed in the scientific literature, as not all universities have the appropriate resources for its implementation and effective implementation, however, in the Central regions in each University it has a special place and transnational (cross-border) education has long acquired the features of the developed direction. In addition, potential applicants are interested in their chosen universities to develop this area of educational services, as it not only gives certain prerogatives for further employment, but also in General for continuing education both in Russia and abroad. The latter is facilitated by the processes taking place in the world, including the processes of integration and globalization in the economy, politics, sociology, pedagogy and others. Confirming this, Shabalin Y.E., Vakhrusheva E.M. write: «... in solving the problems of development and improvement of higher education in individual countries can no longer be based only on the criteria of the national level... to Respond to the global challenges of the XXI century can only globalized high school ...» [1, p. 50].

\section{The concept and methodology of the study}

Universities today, attracting public attention, as well as increasing the importance of higher education, are a guide for a person in his future employment and a vector of professional growth and development. An integral part of the educational activities of the universities of the present and future is the involvement in the scientific space of all, from the teaching staff and ending with children, who will have to receive demanded and adapted to modern economic conditions education.

At the same time, Panibratzev A.V. points out that «... knowledge is recognized as the Main engine of progress and the greatest value in the world, therefore, the higher school of every state striving for progressive development must meet some common requirements for the whole world in order to meet the conditions imposed on education by the new system of economy and the new system of international order ...» [2, p. 49].

The described requirements are embodied in the modern directions of globalization, which today have an impact on the active development and maintenance of higher education in all professional areas of the world scientific and educational space, however, without taking into account the natural vector of development for each existing education system.

Globalization is one of the dominants of intensive development of all spheres of activity and here education has found its rightful place. So, Sedunova S.Y., believes that «... globalization of the world economy has led to significant changes in the organization of labor, production of goods and services, including educational services, relations between countries, affecting even the culture of individual Nations ...» [3, p. 204].

Research methods - content analysis, comparative analysis, generalization, interpretation.

\section{Results and and discussion}


At the first stage, content analysis was carried out. Cross-border education, which is also a part of globalization processes, is a kind of panacea for many regional universities in raising their own image, accreditation and professional development. All this turns out to be only prerequisites. But not all universities effectively use the tools provided by market changes to enter the global educational process. The lack of technical, material and flexible information and communication base, which are of significant importance for improving the educational process, does not bring positive results in achieving quality and standards of global importance.

As a result of globalization, the labor market has formed, its transformation is still taking place with new trends in the global labor market, against which different countries are interested in attracting an intellectual product with similar requirements for knowledge and competencies, which, in turn, «... leads to the creation of global thinking to manage global processes in all spheres of life...» [3, p. 204].

Fundamentally, transnational or cross-border education means «... all types of higher education programs, or courses of study, or educational services, including distance education, in which students are not located in the country where the main University providing vocational education is located, but in another country. Programs may belong to the educational system of a foreign country or be implemented independently of any national education system...» [4, p. 73].

The second stage of the study is a comparative analysis and justification of the purpose of the study. Don State Technical University is one of the leaders in the region among educational institutions for the implementation of cross-border educational programs. This is actively promoted by the service of international education established on the basis of this University. The mission of this service - «... to promote the implementation of the University of the basic tools of the Bologna process and the integration of the Don State Technical University in the international educational space ...» [5, p. 2].

The intensive development of General education at the University gave impetus to the active and progressive use of information and computer technologies, the formation of electronic global libraries, the creation of scientific areas, the development of research activities and its integration with other universities not only in Russia but also in Europe, Asia and other economic and educational conglomerates.

In addition, the development of distance education makes it possible to simultaneously study at several universities in different countries, which allows to improve the level of knowledge, increase the quality and experience of education. Modern information and computer technologies, which are an important tool for cross-border education, expand the opportunities for the introduction of inclusive education, which is now also put at the head of professional educational activities of the don state technical University in the context of cross-border education.

The same is stated by Rasha E.E. «... Researchers of transnational education identify several factors influencing its development: the development of information and communication technologies that provide new opportunities and opportunities for educational cooperation and cooperation at the international level; the emergence of corporate educational services; the development of higher education without borders ...» [6, p. 220].

The emergence of new types of providers such as «... international companies operating in Russia, commercial, financial institutions, corporate or United universities, as well as IT and media companies ...» [7, p. 8], leads to the development of cross-border education in regional universities and Don State Technical University can find a worthy place in the cross-border education of the southern Federal district.

The main tasks of the international education of the Don State Technical University include: «... on the basis of interaction with foreign educational institutions, Foundations, 
Associations to develop and improve the educational process of the University» [5, p. 5]; in order to implement international projects, standards and programs to establish partnerships and implement cooperation of the University with educational institutions and organizations of foreign countries; based on the experience and professionalism of the University «... to carry out information and consulting support of international educational projects and programs implemented at the Don State Technical University, including academic mobility programs ...» [5, p. 5].

Given the scope of activities of the Don state technical University in the regional market, we believe that such a range of tasks on cross-border education is insufficient. Today, the modern directions of educational activities of the Don State Technical University should be combined, in particular, inclusive education is also important to integrate into the international context, volunteer movements can be United by common directions, ideas, means and methods of implementation in the international educational space. In our opinion, everything is different - each of these areas of educational activity at the University develops independently, which is not effective enough.

On the other hand, the question arises whether regional universities can provide their students with quality programs of international education and international level?

This question is justified by the results of the author's monitoring of the teaching staff. It was found that, despite the slow, but «rejuvenation» of scientific personnel, teachers are not ready to implement international programs, because their level of competence is still insufficient to ensure high quality education of students who are able to realize their knowledge and skills in the global economy.

The third stage is aimed at processing the results of the study. Thus, among the 29 teachers of the University aged 25 to 45 years, only 11 speak English at the level of international standards. 4 specialists teach educational material in English and/or other foreign language, including for foreign students.

7 representatives of the teaching staff have individual (without co-authors) publications in journals of international citation databases, including in English and/or other foreign languages. At the time of the study, none of the surveyed teachers did not provide the author's inventions, had no patents, state achievements in the field of higher education.

Currently, the trend is the protection of diploma projects in English and/or other foreign language, which is also not actively practiced in Don state technical University and among the teaching staff.

In our study of 29 teachers over the past 3 years, only 7 prepared with students final qualifying work in English. Representatives of the teaching staff note the low interest of students, and this mainly depends on how the University promotes this practice. Protection of final qualifying work in English gives an additional guarantee to the graduate in employment abroad and full adaptation to the requirements of, for example, European education.

The Don state technical University often holds scientific and practical conferences of regional and international importance, but rarely representatives of the foreign scientific elite are present at these events, and there are no speeches in a foreign language. Our respondents confirmed this fact and for the most part noted the probability that a change in this circumstance would make a positive contribution to the development of cross-border education at the don state University.

In addition, the respondents believe that it is not quite correct to impose participation in international education on the teaching staff and the decision on the deep introduction and penetration of this concept into the General educational process should be discussed collectively.

Currently, international education at the Don state technical University is a General concept, which, as mentioned, is laid down in a certain resolution and is implemented as 
foreign students enter. However, this approach is not forward-looking and productive. We noted that neither the faculty nor the students have a high degree of interest in the development of cross-border education at the University, which is associated with objective and subjective reasons.

The objective reasons include the lack of incentives for the professional growth of the teaching staff, the subjective - not enough high level of training to implement in the educational process in all areas of the University international programs adapted to the modern requirements of both cross-border education and economic conditions.

In this context, we should not focus only on the Don state technical University. We assume that other regional or local universities can show even less good results on these characteristics.

However, young scientists are more flexible and adaptive to the new criteria of international education and, as a result, can quickly accept the conditions that dictate the world labor market. In this case, the Don state technical University can develop a program of training and/or professional development of the teaching staff, in the course of which teachers can improve not only the professional level in cross-border education, but also to allocate prerogatives in the analyzed issue. Thus, the integration of two areas of educational activities of the Don state technical University - cross-border and inclusive education will be effective. This, in turn, will expand the boundaries of the scientific space of the University and raise the image over other universities in the region, which in the context of globalization and high level of competition is an important indicator of quality and professionalism.

In our opinion, «... competence approach to the improvement of the educational process and, in particular, - the educational classroom process, should be discussed more deeply, commensurate with the development of General trends in the markets of education, labor and technology. In the opposite case, universities produce specialists who do not professionally meet the requirements of employers, market, economic and social situation ...» $[8$, p. 133].

\section{Conclusion}

Thus, at present, international education in the regions does not correspond to the quality of education in the world scientific space, it is not adapted to the needs of foreign students and faculty of universities, so the students themselves do not show the desired interest in international education at the don state technical University. Many universities are trying to develop cross-border education to create an external image and attract as many students as possible, without taking into account the trends and realities of international education, culture, traditions and the meaning of its development in international universities. Based on foreign research, it can be concluded that «... this increases the vulnerability of students and other stakeholders to poor quality services and unscrupulous service providers of crossborder higher education ...» [9, p. 200].

In the Service of international education of the don state technical University today it is possible to intensify work through the introduction of new tools of cross-border education, which is used in other countries. The positive experience of the world universities in this direction should be the starting point in the development of cross-border education, but the don state technical University can maintain its own mission and concept, established traditions of the University in international education, the program and tasks, which, however, should be expanded to intensify the integration of the educational process into the world standards.

The monitoring of the opinions of the teaching staff conducted by the authors of this 
article allowed to draw conclusions that the don state technical University needs its own tools of training (training) of the teaching staff in order to adapt teachers to the current trends of cross-border education.

Further, it is necessary to expand international relations by broadcasting the concept of the University to interested subjects of international education in the countries of the former CIS, Europe, Asia, etc.

It is also important to pay attention to the infrastructure of the University to combine efforts to integrate international and inclusive education and bring them to a higher level by attracting Federal, regional and foreign investors, patrons and members of the public to the development of cross-border education as an indicator of the development of the region. Don state technical University today is quite active in the aspect of cross-border education and the author's strategy of its development and maintenance at the modern level will strengthen the position in this area of educational activities and more profitable to offer future professionals educational services.

The vector in this direction can be sociological research, allowing to identify priorities in the areas of educational activities of the University and on the basis of the results to work out a new strategy of the international education Service of the don state technical University.

\section{References}

1. Y.E. Shabalin, E.M. Vakhrusheva Council of rectors. Internationalization of the Russian higher education system: cross-border and international University education. 1, 50-59 (2015)

2. A.V. Panebratzev, Sci. herald MSTU. Globalization and problems of higher education in Russia (2014) URL: https://cyberleninka.ru/article/n/globalizatsiya-i-problemyvysshego-obrazovaniya-v-rossii-1

3. S.Y Sedunova, Bulletin of PSU. Cross-Border education: theory and practice, possibility and reality, 13, 204-209 (2011)

4. G.A. Lukichev, Bulletin RUDN. Transnational education. 1. 71-75 (2002)

5. Regulations on the Service of international education of DSTU. Functions of the international education Service. 1, 1-23 (2014)

6. E.E. Rusha, News of the RSPU A.I. Herzen. 161, 219-224 (2013).

7. A.I. Shineaway, Bulletin UMO. 2, 8-13 (2011)

8. A.G. Bezpalova, A.N. Legkonogikh, Human capital. 5, 132-140 (2019)

9. S. Vincent-Lancrin, S. Pfotenhauer, Bulletin of IO. 8(1), 199-263 (2013) 